This item was submitted to Loughborough's Research Repository by the author.

Items in Figshare are protected by copyright, with all rights reserved, unless otherwise indicated.

\title{
Introduction: studying populism in European party systems
}

PLEASE CITE THE PUBLISHED VERSION

http://www.palgrave.com/page/detail/populist-parties-in-europe-stijn-van-kessel/?K=9781137414106

\section{PUBLISHER}

Palgrave Macmillan

VERSION

AM (Accepted Manuscript)

\section{PUBLISHER STATEMENT}

This work is made available according to the conditions of the Creative Commons Attribution-NonCommercialNoDerivatives 4.0 International (CC BY-NC-ND 4.0) licence. Full details of this licence are available at: https://creativecommons.org/licenses/by-nc-nd/4.0/

\section{LICENCE}

CC BY-NC-ND 4.0

\section{REPOSITORY RECORD}

Van Kessel, Stijn. 2019. "Introduction: Studying Populism in European Party Systems". figshare. https://hdl.handle.net/2134/18410. 


\section{I ntroduction: Studying Populism in European Party Systems}

From: Stijn van Kessel (2015) Populist Parties in Europe. Agents of Discontent?, Basingstoke: Palgrave Macmillan, Chapter 1 (pre-copy edited version).

I am deeply concerned about the divisions that we see emerging: political extremes and populism tearing apart the political support and the social fabric that we need to deal with the crisis; disunion emerging between the centre and the periphery of Europe; a renewed demarcation line being drawn between the North and the South of Europe; prejudices reemerging and again dividing our citizens.

José Manuel Barroso

It may be clear that populism, a term part of European Commission President Barroso's gloomy prognosis, is often associated with developments which are deemed adverse, or even dangerous. Particularly since the dawn of the financial and economic crisis in 2008, various European political actors have expressed their concern about the rise of populism, more often than not associating the concept with political extremism and xenophobia. Yet what precisely constitutes this 'populism', and which political actors embody it, is often left unsaid. This books aims to clarify the manifestation of populism in European politics between 2000 and 2013. The focus is on political parties, since these are still the key actors in contemporary European politics in terms of democratic representation. I first aim to apply the concept of populism to party systems across the continent and to identify parties that stand out from the others in terms of their consistent expression of a populist discourse. Secondly, I seek is to explain the electoral performance of those 'populist parties' in national elections. Does the success of these parties in Europe denote a reactionary and destructive mood, as certain commentators and representatives of the political elites would like us to believe, or is this interpretation incomplete, or even flawed? 
It is something of a cliché to start a text on populism with the observation that agreement on a definition is lacking and that the term is used for many different types of actors through time and space. Although this may still be true, there has been a surge in academic contributions on populism in recent years, and many scholars - at least those who apply the concept with care - tend to talk about the same phenomenon when they use the term. Populism is generally associated with a Manichean vision of society (pitting the good 'people' against the corrupted 'elites'), a conception of 'the people' as a homogeneous entity, and a defense of popular sovereignty (see e.g. Taggart 2000; Mudde 2004; Abts and Rummens 2007; Albertazzi and McDonnell 2008a). While many scholars broadly agree on what populism is, it is still debated in what form populism manifests itself. Disagreement exists about whether populism can best be seen as a strategy, a style, or a political ideology. This, in turn, makes it unclear whether the term populism denotes an ideological attribute of a bounded set of political actors, or whether it constitutes an (opportunistic) rhetorical tool which can be applied by any politician. By relating the concept of populism to party systems in Europe and aiming to identify 'full' cases of populism, I seek to shed more light on this question.

Although the academic debate on populism may be well developed, in the vernacular sphere the term is applied in a less precise way (Bale et al. 2011). In the European context, populism is habitually associated with xenophobic politics and parties of the extreme or radical right (and therefore considered to be dangerous). This is not surprising, since populism in Western Europe has often been expressed by parties characterised by a nationalist and culturally conservative ideology, and hostility towards immigration and multiculturalism. The European academic literature has therefore also mainly considered populism as an element of 'the right' (see e.g. Betz 1994; Kitschelt and McGann 1995; Betz and Immerfall 1998; Mudde 2007). Populism, however, is not necessarily related to xenophobic politics or to any of the other properties of the radical right. Outside of the European context, populism is actually often associated with politicians, parties and movements of a very different kind (see Ionescu and Gellner 1969; Canovan 1981; Taggart 2000; Mudde and Rovira Kaltwasser 2013). Although the 
focus of this study is on Europe only, this book considers also cases of populism beyond the radical right, as I am interested in the phenomenon of populism (expressed by political parties) in itself.

Another feature of the literature on populism in Europe is that it, at least until fairly recently, predominantly dealt with long-established democracies in Western Europe (e.g. Albertazzi and McDonnell 2008a). Although contributions have also emerged on populism in post-communist countries (e.g. Havlík et al. 2012), pan-European research projects have remained scarce. Since many Central and Eastern European countries have been marked by the legacy of communism, it was difficult to provide a meaningful comparison between the party systems of long-established and post-communist European countries. Almost a quarter of a century has now passed since the postcommunist countries' transition to democracy, and many of these countries have joined the European Union. While it would be wrong to disregard the still prevailing differences, it now makes sense to compare parties and party systems across the whole of Europe. Cas Mudde (2007) and Luke March (2011) set an example in their studies on populist radical right and radical left parties, respectively. This book has a pan-European scope as well, and provides a systematic analysis of populism and the electoral performance of populist parties in party systems across the continent.

By taking this general approach, including populist parties with different ideological traits and analysing them in a wide variety of countries, it can be expected that the study will include cases that have little in common apart from their populism. This is in line with the notion that populist parties are 'chameleonic' in the sense that they adopt an ideological 'colour' and focus on issues relevant to their specific context (Taggart 2000). As far as their electoral performance is concerned, this study assesses whether, in spite of ideological differences, the success or failure of populist parties is dependent on the same logic. Whereas many comparative studies on the electoral performance of populist or other radical 'challenger' parties have focused on institutional variables, the economic and political context, and positions of mainstream competitors, the role of the challenger parties themselves has often been overlooked (see Mudde 
$2007 ; 2010)$. This study explicitly concentrates on the electoral credibility of populist parties themselves. In addition to the presence of a conducive environment, the agency of populist parties is deemed crucial in explaining their electoral performance.

As will be discussed in more detail towards the end of this chapter, the electoral performance of populist parties in national elections will be assessed through a mixedmethods approach. My first analysis assesses populist party success and failure in 31 European countries (EU-28 plus Iceland, Norway and Switzerland) by means of Qualitative Comparative Analysis (QCA) techniques. QCA can demonstrate how different (combinations of) explanatory conditions underlie the same outcome across various contexts. This is of crucial importance in view of the diversity of populist parties and countries studied in this book. After this analysis, the book continues with three qualitative case studies, which provide an in-depth analysis of populist parties and their competitors in the Netherlands, Poland and the United Kingdom. The first two countries have experienced the rise as well as the fall of populist parties after 2000 , while populist challengers have been unsuccessful in UK general elections.

On the basis of the analyses in this book, several key messages can be formulated. For one, it is important to avoid using the concept of populism too indiscriminately to describe or classify political parties. Some parties may voice populist rhetoric only sporadically and for a limited amount of time, and grouping these parties together with more genuine cases of populism leads to conceptual confusion and misclassification. Several post-communist countries pose a challenge in particular. Due to the more general presence of anti-establishment sentiments in these countries, it is difficult to distinguish between populist and non-populist parties. As far as electoral performance is concerned, the rise of a populist party in a given country ought not to be seen as a mere reactionary backlash, but rather as the result of a perception that established political parties are unresponsive with regard to certain salient political themes. Populist parties, at the same time, only do well if they present themselves as credible alternatives to the political establishment. This means that researchers should pay more attention to the agency of populist parties in their effort to explain their 
success and failure. Populist parties are fairly ordinary players in the domain of party competition and they should not be dismissed as dangerous pariahs out of hand, as their rise tells us something about the state of representative democracy (e.g. Canovan 1999; Mény and Surel 2002; Taggart 2002; Panizza 2005; Rovira Kaltwasser 2013).

The remainder of this chapter discusses the conceptual, theoretical and methodological starting points of this book. First, I provide a brief overview of the academic use of the concept 'populism', followed by a discussion on how populist parties can be defined and identified. I will then turn to my explanatory framework concerning the electoral performance of populist parties in Europe. The remaining section discusses the study's research design and the outline of the book.

\section{[A] (Problems of) populism}

The concept of populism is not new, but its application in scholarly contributions has witnessed a surge in the past few decades, especially where the European context is concerned. This went hand in hand with the appearance of political parties in Western Europe which were often described as extreme- or radical right-wing, and also 'populist' (e.g. Ignazi 1992; Betz 1994; Kitschelt and McGann 1995; Taggart 1996). ii It is important to recognise that studies on populism in other parts of the world, such as the United States (e.g. Kazin 1998; Ware 2002) and Latin America (e.g. Weyland 2001; Roberts 2006; Mudde and Rovira Kaltwasser 2013), include political actors of a different kind. As this book focuses on populist parties in Europe, the main aim of this concise literature overview is to outline the main issues faced when applying the concept in the European context. I will first introduce frequently identified elements of populism and several definitions, and then touch on discussions about the manifestation of populism and its relationship to democracy. In the subsequent section I will discuss in more detail the elements central to the definition of 'populist parties' I apply in this book. 
[B] Populism and its manifestation

One of the earliest accounts in which populism is described quite systematically is not devoted to the concept as such. Edward Shils (1956) discussed populism in his book on American security policies and associated anti-Communist senator McCarthy with the term. According to Shils (1956: 101), populism is 'tinged by the belief that the people are not just the equal of their rulers; they are actually better than their rulers and better than the classes - the urban middle classes - associated with the ruling powers'. Populists are highly sceptical of bureaucracy and impatient with institutional procedures, which supposedly hinder the direct expression of the popular will. Politicians would have to be 'at best errand boys with little right to judgement on their own behalf if that judgement seems to contradict popular sentiment' (Shils 1956: 103).

The ground-breaking edited volume of Ghiţa Ionescu and Ernest Gellner (1969) showed that the use of the concept was by no means restricted to the American context. iii The editors observed that populism was used to refer to actors from a wide range of countries and ideologies. In search for common elements of populism, the individual contributions touched on a range of cases, including the $19^{\text {th }}$ century movements in the US and Russia, and $20^{\text {th }}$ century populism in Latin America, Africa and Eastern Europe. The various authors identified a broad range of populist attributes. Peter Wiles (1969: 166), for instance, argued that populism is based on the premise that: 'virtue resides in the simple people, who are the overwhelming majority, and in their collective traditions'. Wiles subsequently composed a long list of populist characteristics, including the notions that populist movements tend to be leader-centred, loosely organised, anti-intellectual, opposed to the establishment, and nostalgic in their dislike of the present and aim to 'mould the further future in accordance with its vision of the past' (Wiles 1969: 170). Similarly, Angus Steward (1969: 193) emphasised populism's dislike of the state in its present form, and parliamentary politics in particular, and also spoke of the 'charismatic' leadership of populist movements. Peter Worsley (1969: 244-6), in turn, argued that populists stress the supremacy of 'the will of the people' and the desirability 
of popular participation in the political process. In the end, however, the Ionescu and Gellner volume showed a reluctance to provide a clear-cut definition of the concept.

In her study on populism, Margaret Canovan (1981) was also pessimistic about a single, globally applicable, approach to populism. After having described a broad range of historical and more contemporary populist movements and politicians across the world, Canovan (1981: 133) argued that it is not possible 'to unite all these movements into a single political phenomenon with a single ideology, program or socioenomic base', and instead distinguished seven general categories of populism. In later work, Canovan further claimed that a single (explanatory) theory on populism will be 'either too wideranging to be clear or too restrictive to be persuasive' (Canovan 1982: 544). It was, according to the author, best to build a descriptive typology 'which clarifies the ways in which the term is used while being spacious enough to do justice to the diversity of the movements and ideas concerned' (Canovan 1982: 550).

Several authors have, more recently, been less reluctant to provide a clear definition, or a universally applicable description, of populism. In his construction of an ideal type, Paul Taggart (2000: 2) identified six key themes: populism is hostile towards representative politics, identifies with an idealised 'heartland', lacks core values, is a reaction to a sense of crisis, is self-limiting and episodic, and has a 'chameleonic' character. Cas Mudde (2004: 543), in turn, defined populism as 'an ideology that considers society to be ultimately separated into two homogeneous and antagonistic groups, 'the pure people' versus 'the corrupt elite', and which argues that politics should be an expression of the volonté générale (general will) of the people'. Daniele Albertazzi and Duncan McDonnell (2008b: 8) added a third group (the 'others') in their definition of populism as 'an ideology which pits a virtuous and homogeneous people against a set of elites and dangerous 'others' who are together depicted as depriving (or attempting to deprive) the sovereign people of their rights, values, prosperity, identity and voice'.

As is evident from the last two definitions, populism is in recent years often perceived as an ideology or, more specifically, a 'thin' or 'thin-centred' ideology (Mudde 2004; Abts and Rummens 2007; Stanley 2008; Rovira Kalwasser 2013). Following 
Michael Freeden (1998: 750), a thin-centred ideology is an ideology 'that arbitrarily severs itself from wider ideational contexts, by the deliberate removal and replacement of concepts'. Along these lines, populism as such lacks a 'programmatic centre' and ideas about how deal with societal issues, but it can 'cohabit' with more comprehensive ideologies (Stanley 2008: 100; Rovira Kalwasser 2013: 9). This is similar to Taggart's (2000) assertion that populism is chameleonic in adopting the ideological colour which resonates with the values of the 'heartland' in which the people reside. This is not to say that there is little substance to the populist ideology; following Stanley (2008: 100), 'the absence of a common history, programme and social base, whilst attesting to populism's 'thin' nature, does not warrant the conclusion that there is no coherence to the collection of concepts that comprise populist ideology'.

It would appear that treating populism as a (thin) ideology implies that there are political actors with populism as a defining ideological attribute. Indeed, in the European context observers often speak of 'populist parties' or party families for which populism is a core component. Mudde (2007), for instance, has treated populism as a core element of the populist radical right, and also identified two other types of populist parties: neoliberal populists and social populists (see also March and Mudde 2005; March 2011). Even though it would not be accurate to speak of a populist 'party family' (see Mair and Mudde 1998), for populist parties are not united in the policy positions they take, populism can still be seen as an important core attribute of certain types of parties.

Yet populism is certainly not always treated as a core ideological element of a certain type of movement, party, or politician. An alternative approach is to define populism as an (opportunistic) strategy, employed to generate or retain support. HansGeorg Betz (2002: 198), for instance, asserted that populism could be viewed a rhetoric 'designed to tap feelings of ressentiment and exploit them politically'. In his study of populism in Latin America, Kurt Weyland (2001: 14) argued that 'populism is best defined as a political strategy through which a personalistic leader seeks or exercises government power based on direct, unmediated, uninstitutionalized support from large numbers of mostly unorganized followers'. 
Yet another approach is to perceive populism as a 'style'. Jagers and Walgrave (2007: 322), for instance, distinguished between 'thick' and 'thin' populism, and argued that the latter form is simply 'a communication style of political actors that refers to the people'. Populism is, in this sense, not necessarily associated with a certain type of movement or party, but can also be applied by actors such as interest group representatives and journalists. More recently, Moffitt and Tormey (2013) have also argued that it is best to define populism as a style, and to focus on its 'performative' and 'aestetic' features. Populism, according to the authors, should be seen in the context of the decline of traditional ideological cleavages and the increased 'stylisation' of the political, which goes together with a simplification of political discourse, the formulation of 'neat us-against-them antagonisms' and 'sound-bite solutions' (Moffitt and Tormey 2013: 7). It may even be argued, then, that there is scope for a more general populist 'mood' in contemporary politics. Indeed, Mudde (2004) spoke of a populist Zeitgeist, and argued that the emergence of the radical populist parties in Western Europe has encouraged mainstream parties to use populist methods themselves (see also Mair 2002; Pappas 2013).

From an empirical perspective, the fact that there are different interpretations concerning the manifestation of populism is not necessarily problematic, as long as there is a consensus about the concept's attributes. It seems reasonable to argue that populism can occur in various forms (e.g. style, strategy and ideology) and that its expression is not confined to a delineated set of political actors. As a matter of fact, recent contributions have measured the degree of populism in the discourse of political parties and politicians, through content analyses of party manifestos, speeches or party political broadcasts (Jagers and Walgrave 2007; Hawkins 2009; Deegan-Krause and Haughton 2009; Pauwels 2011a; Rooduijn et al. 2012). In doing so, the question of whether populism is an ideology, strategy, communication style or something else, might not be very important.

Accepting that the distinction between populism and non-populism is a matter of degree rather than kind does make life harder for those who seek to apply populism as a 
'classifier' (Sikk 2009); that is, to use the concept in order to discriminate between certain types of politicians or party families. It is far from straightforward to determine how much populism a party should express in order to classify it as a 'genuine' populist party. What is more, some scholars even question the usefulness of an 'in-or-out' type of classification in the first place (see Deegan-Krause and Haughton 2009; Sikk 2009; Rooduijn et al. 2012). Rejecting completely the value of this 'dichotomous' approach, however, seems overly drastic. The scope for 'border disputes' also exists where other types of parties are concerned, and for some political actors populism is evidently more than a disposable rhetorical devise. The study of these political actors is important, as the rise of populism tells us something about the state of representative democracy.

\section{[B] Populism's relationship with democracy}

As discussed at the start of this chapter, it is common to see populism as a threat, or at least as an adverse phenomenon. Populism is regularly applied as a synonym for demagoguery, simplistic solutions or opportunism (e.g. Mudde 2004; Taggart 2000: 5; Di Tella 1997), and especially in the vernacular sphere the term is often used pejoratively to refer to vote-winning policy proposals, attempts to pander to public opinion or antiimmigration attitudes (Bale et al. 2011). Yet also in scholarly literature the term is frequently seen as a negative phenomenon. Hans-Georg Betz (1994: 4), for instance, sees populism as a means of political opportunism that is unscrupulous and exploitative of the anxieties of the electorate. Others have seen a threat in populism's espousal of unmediated popular sovereignty, which is considered to come at the cost of liberal democratic 'checks and balances' and the protection of minorities. Abts and Rummens (2007), for instance, argued that populism is inherently incompatible with democracy; populism's conception of the people as a homogeneous body is fictional and 'generates a logic which disregards the idea of otherness at the heart of democracy and aims at the suppression of diversity within society' (Abts and Rummens 2007: 414).

A more optimistic reading is that populism is an important indicator for the health of representative or liberal democracy. Some scholars have argued that populism 
emerges when the political elite loses track of public opinion, or when the 'constitutional' or 'liberal', as opposed to the 'democratic' or 'popular' pillar of democracy, becomes too dominant. Taggart (2002: 63), for instance, argued that populism acts as a 'bellwether' for the health of representative politics. Mény and Surel (2002: 17) have described populism as 'a warning signal about the defects, limits and weaknesses of representative systems', and argued that 'in spite of its often unpleasant tones, it may constitute an effective reminder that democracy is not a given, but is instead a constant enterprise of adjustment to the changing needs and values of society'. Canovan (1999: 11) wrote about the tension between the 'pragmatic' and 'redemptive' faces of democracy and argued that:

When too great a gap opens up between haloed democracy and the grubby business of politics, populists tend to move on to the vacant territory, promising in place of the dirty world of party manoeuvring the shining ideal of democracy renewed. Even from the point of view of pragmatic politics, the vital practices of contestation and accountability grow weak without the energy provided by democracy's inspirational, mobilizing, redemptive side.

Still, populism is seldom seen as an unequivocally good thing. Not many scholars appear to subscribe to Ernesto Laclau's argument that populism and democracy are essentially interchangeable terms and that the end of populism coincides with the end of politics' (Laclau 2005: 48). Francisco Panizza (2005: 30) instead described populism as a 'mirror in which democracy can contemplate itself', but argued that 'populism is neither the highest form of democracy nor its enemy'. In the same volume, Benjamin Arditi (2005) argued that populism can appear in three possible modes: populism as a mode of representation, a symptom, or as an underside. The first mode is compatible with liberaldemocratic politics, the second presents a disturbance of democracy, whereas the latter entails an actual interruption of democracy. Gianfranco Pasquino (2008: 28), in turn, argued that the appearance of populism is often a sign of a poorly functioning democratic 
regime, but that populism, for instance due to its unrealisable promises, has a negative impact on the democratic framework itself.

In a more recent edited volume of Cas Mudde and Cristóbal Rovira Kaltwasser (2012), an attempt has been made to move beyond theoretical assumptions about the relationship between populism and democracy, and to test empirically the consequences of populism in several countries in Europe and the Americas. Based on the various case studies, the editors conclude that populism can be a corrective as well as a threat to democracy. Populism can, for instance, place issues on the agenda which have been ignored by the political establishment and give voice to excluded sections of society, but, especially in unconsolidated democracies, can also undermine liberal democratic institutions in view of its monist conception of society and disdain for 'checks and balances'.

The theoretical observations made by several of the aforementioned authors thus seem to have empirical consequences, also for populist parties in the European context. For my study it is particularly relevant that populist parties seem to mobilise in situations where the political establishment is seen as unrepresentative, or unresponsive to the demands of a certain segment of the electorate. The chapter will later turn to the analytical framework of this study in more detail. The following section first discusses how populist parties can be defined and identified in the European context.

[A] Defining and identifying populist parties

\section{[B] Defining populist parties}

In this book I seek to use the concept of populism to classify political parties in Europe and, through this, to investigate whether it makes sense to distinguish between populist and non-populist parties. I start out from the idea that populism can be a durable defining attribute of certain political parties, and thus potentially more than an (opportunistic) strategy or style. Populist parties embody resistance against the political 
establishment in defence of popular sovereignty, and it would be impossible to characterise such parties without taking their populist anti-establishment discourse into account. The way populism is applied here is in line with the accounts considering populism to be a 'thin' ideology; populist parties do not all adopt the same substantive policy positions. This does not mean, however, that the populist element of these parties is completely unrelated to their more concrete policies. This will be discussed further in the following section. In order to identify the populist parties in contemporary Europe, this study seeks inspiration from the previously mentioned contributions that treated populism primarily as a set of ideas. Even though differences can be noticed, there is a substantial overlap between recent definitions of populism. Four crucial, distinct but interrelated, populist properties are captured well by Ben Stanley (2008: 102):

- The existence of two homogeneous units of analysis: 'the people' and 'the elite'.

- The antagonistic relationship between the people and the elite.

- The idea of popular sovereignty.

- The positive valorisation of 'the people' and denigration of 'the elite'.

Although populism is regularly assumed to portray both 'the people' and 'the elite' as homogeneous entities - thereby emphasising the normative distinction between the two groups (Mudde 2004: 544) - authors have mainly described populism's monolithic conception 'the people' (e.g. Taggart 2000; Abts and Rummens 2007; Albertazzi and McDonnell 2008b). iv Populists speak of 'the people' as if it were a clearly circumscribed and homogeneous group, and tend to ignore the differences between its members. It is not always self-evident who belong to 'the people', and populists are often not very specific about their target audience themselves. To do so would actually limit the populist appeal. In the words of Arditi (2005: 82):

(...) the populist 'us' remains conveniently vague. It is a deliberate vagueness, for it enables it to blur the contours of 'the people' sufficiently to encompass anyone with a 
grievance structured around a perceived exclusion from a public domain of interaction and decision hegemonised by economic, political or cultural elites.

Populist parties, in other words, profit from an elusive characterisation of their target constituency, as it enables them to appeal to a broad disgruntled audience. That is not to say that the appeal to the ordinary people is entirely random. In the words of Taggart, populists identify with an idealised and imagined 'heartland', which is the place where 'the people' reside (Taggart 2000: 95). The features of the heartland are usually based on a romanticised portrayal of the past and constitute the elements of the community which are considered worth defending. Consequently, populist actors across time and space each construct their own particular version of the heartland.

Even if the heartland concept helps in making sense of who 'the people' are meant to be, populist parties are usually clearer about who does not belong to their portrayed heartland. The conception of 'the people' is, then, typically constructed in a negative manner (Taggart 2000; Mudde 2004; Albertazzi and McDonnell 2008b). In the words of Taggart (2000: 3), populism 'excludes elements it sees as alien, corrupt or debased, and works on a distinction between the things which are wholesome and those which are not'. It can be argued that populism is intrinsically exclusionistic, in view of its monolithic portrayal of 'the people' and its, therefore perhaps inherent, rejection of pluralism (Mudde 2004: 543; Abts and Rummens 2007).

Immigrants and ethnic or cultural minority groups are easy targets to brand as outsiders. Not all populists are necessarily xenophobic, however, and the heartland can also be defined in non-ethnic terms. Mudde and Rovira Kaltwasser (2013: 167), for example, argued that European populism primarily has an 'exclusionary' character (excluding the 'aliens'), but that populism in Latin America is more oriented towards the socio-economic dimension, and primarily focuses on 'including the poor'. Left-wing populists in Europe also tend to place more emphasis on socio-economic themes in their distinction between the elite and 'the people' (see March 2011). Thus, in the words of 
Rovira Kaltwasser (2013: 10), populists may conceive of 'the people' as the 'ethnos' as well as the 'plebs' (or a combination of the two).

This category of 'elites', in turn, can be defined broadly, and comprise the corporate rich, bankers, but also the media or intelligentsia whose (liberal) ideas, values and interests are at odds with those of the 'silent majority' (Canovan 1999: 3). Both populist core concepts, 'the people' and 'the elite', are thus 'empty vessels', which can be filled in different ways, depending on the context and ideological features of the populist party (see Mudde and Rovira Kaltwasser 2013: 151). If we speak about populism in the form of political parties, the national political establishment inherently belongs to the 'elite' category. In electoral competition, the 'established parties' are the main antagonists of populist parties, and portrayed by the latter as the henchmen of 'special interests' (Mudde 2004: 561). Residing in their ivory towers, the members of the political establishment are alleged to have lost track of the everyday problems of the ordinary people. In their denunciation of the whole political establishment, populist parties' criticism goes further than condemning a specific government for being unresponsive or corrupt. In practice, however, populist parties are likely to target traditionally dominant parties or parties with opposing ideological traits. Populist parties, in order words, may be rather selective in picking their enemies (and potential allies).

A final note is that populist parties do not necessarily intend to get their following directly involved in politics, even if many support referenda and other forms of direct democracy. Following Robert Barr (2009), populism can be associated with a plebiscitarianist form of linkage between citizens and the political elite; populism emphasises the need for accountability of leaders, but rather less the need for political participation by citizens. Populism is thus not necessarily incompatible with representative politics, since populist parties can claim to offer responsive leadership, and to act as the voice of the people (see Mudde 2004; cf. Taggart 2000).

These issues considered, political parties are here classified as populist parties if they: 
1) portray 'the people' as virtuous and essentially homogeneous;

2) advocate popular sovereignty, as opposed to elitist rule;

3) define themselves against the political establishment, which is alleged to act against the interest of 'the people'.

A few further points of clarification should be made. First of all, this definition should be treated as a minimal definition, which includes necessary and jointly sufficient properties, and excludes the attributes that are considered to be 'accompanying properties' (Sartori 1984: 55-6). 'Populist party' is thus treated as a 'classical concept', meaning that all three properties outlined above need to be present in order to speak of a populist party. Alternative strategies of concept formation would be the 'family resemblance' approach and the construction of 'radial categories' (see Collier and Mahon 1993). The latter strategy entails the creation of a central subcategory which can be considered as a 'full' instance, because it incorporates all possible components of a concept. The concept, however, may still be used for cases that lack some of these components. vi The family resemblance structure is even more flexible, in that it contains no necessary defining properties (Goertz 2006: 7; 45). The absence of one of the concept's properties can be compensated by the presence of another.

These approaches, however, are not suitable for the concept of a populist party. None of the components in the above definition can be left out, or substituted, without deriving the concept of its specific meaning and causing 'concept stretching' (see Sartori $1970 ; 1991)$. That is, too wide a variety of political parties would become associated with populism (Weyland 2001; Sikk 2009). Excluding the first two components of the above definition, for instance, leads to the potential inclusion of any kind of (new) antiestablishment party. A reference to popular sovereignty only, on the other hand, does not automatically imply a normative distinction between the people and the political establishment. If the conception of the people as a homogeneous entity is left out of the definition, a crucial element of the populist vision of society would be ignored. In using a minimal definition to identify populist parties, the approach in this study deviates from 
studies treating populism as an 'ideal type' (e.g. Taggart 2000; Zaslove 2008), or distinguishing between categories such as 'thin' and 'thick' or 'soft' and hard' populism (Jagers and Walgrave 2007; Lang 2005).

Another issue to raise is that populism is often associated with characteristics which I consider to be 'accompanying properties', and thus not directly relevant in determining whether or not a party is populist. Some of these properties relate to the alleged style of populists, and include the use simplistic and coarse language and the 'colourful' image of populist leaders (Moffitt and Tormey 2013). Two other frequently identified attributes relate more to the organisational attributes of populist politics: personalistic (or 'charismatic') leadership and the lack of a developed party organisation (e.g. Weyland 2001; Di Tella 1997; Barr 2009). There may indeed be a tendency for populist parties to be underinstitutionalised and reliant on personalistic leadership, in view of their quasi-religious message of salvation and their dislike of traditional party organisations (Taggart 2000: 101-2). Yet I do not consider these organisational features to be defining properties of populist parties, since I concur with Mudde's (2004: 545) argument that charismatic leadership and direct communication between leader and followers 'facilitate rather than define populism'. The use of simplistic and politically incorrect language, in turn, should primarily be seen as a consequence of the populist thin ideology; in particular populism's antagonistic position vis-à-vis the political establishment and its appeal to the 'common' people.

In theory, a party can be populist without showing typical organisational or stylistic features, and populism should essentially be seen as a set of ideas (see also Rooduijn 2013). The way populist parties organise and express themselves is here considered an empirical rather than a definitional matter. Still, as will be discussed later in this chapter, since many populist parties are weakly institutionalised and built around their leader in practice, organisational features are likely to play an important role as far as the electoral performance of populist parties is concerned.

A final point to make is that the presented definition is primarily devised to identify populist parties in Europe. The way in which populism manifests itself varies 
considerably across continents, and not everywhere is populism primarily expressed by political parties. Populism is, for instance, seen as a more general feature of US politics (Kazin 1998; Ware 2002), and in Latin America populism is, even more so than in Europe, commonly associated with individuals rather than parties (see e.g. Roberts 2006; Mudde and Rovira Kaltwasser 2012). Even though 'populism' can be defined so that it is universally applicable, my definition of 'populist parties' is primarily useful in the European context, where parties are still key actors in political systems.

\section{[B] I dentifying populist parties}

With the above definition, the identification of a bounded 'universe' of populist parties in Europe is still not an uncomplicated task. The lack of a clear populist archetype, or another basis for identifying cases of populism, poses a first challenge. Populism, after all, does not 'adhere to a single foundational doctrine, political philosopher or intellectual tradition' (Zaslove 2009: 309). Moreover, actors and movements associated with populism rarely use this label to identify themselves (e.g. Worsley 1969: 218). Even though there are exceptions to the rule, vii populism's pejorative connotation is one reason why political actors are not keen on adopting the term for the purpose of selfidentification.

Another issue is that there is a fine line between populist and essentially nonpopulist party families. In some ways, for instance, populists are similar to fascists, communists and minority nationalists in resenting the existing political order and making appeals to an idealised community. There are some crucial differences too, however. Fascists envision a totalitarian, hierarchically organised and organic state in which the people serve as mere parts of a larger whole (see e.g. Hayes 1973; Payne 1980; Griffin 1993). Populism, on the other hand, glorifies the ordinary people within the community, and not the nation-state as such (Albertazzi and McDonnell 2008b: 3). Fascism, like other forms of right-wing extremism, is also anti-democratic, while populism sees the will of the people as the ultimate source of legitimacy. 
Communist parties, in turn, arguably share the populist claim to defend the 'ordinary' and oppressed people. The populist portrayal of the heartland, however, tends to be based on a shared identity which goes beyond class relationships in a strict sense (March and Mudde 2005: 35; March 2009: 127). Even left-wing populists differ from communists, as the former do not subscribe to the notion of Marxist theorists that the proletariat should be liberated from a 'false consciousness' and made aware of its true interests. (see Eyerman 1981). Populists instead claim that the ordinary people are well aware of their interests, and actually idealise the 'common sense' of the people (Mudde 2004: 547; March 2011: 120).

Minority nationalists or regionalist parties, finally, have a clear notion of a communal identity and often share the populist resentment of the central state establishment. Unlike typical populist parties, however, they oppose a political establishment which is portrayed as 'foreign' and as an enemy 'from outside'. Certain parties, such as the Italian Northern League and the Flemish Interest in Belgium, can nevertheless be considered as 'regionalist populist' parties (McDonnell 2006). Yet it is important to stress that minority nationalists are not automatically populist, since they may not subscribe to the notion of popular sovereignty. This also applies to nationalists in general, who are not always anti-elitist and, thus, not always populist (Mudde 2007: 24).

In practice, however, these ideological boundaries may not be that clear-cut. What is more, the literature review previously outlined that populism can also take the form of a more ephemeral rhetorical device, which can be applied by all kinds of parties. As discussed, Mudde (2004) spoke of a populist Zeitgeist, which also influenced the discourse of established parties, and March (2011: 19) argued that since 1989 all radical left wing parties became more populist (and nationalist) in their aim to reach out beyond a traditional working class electorate. However, one should not be overly doubtful about the 'discriminating power' of populism as a concept (Sartori 1970). On the basis of a content analysis of party manifestos, Rooduijn et al. (2012) actually showed that certain 
Western European parties clearly stood out in terms of their populism, while mainstream parties did not become more populist over time.

In post-communist Europe, however, the situation is likely to be less clear-cut. After the fall of communism, it was practically impossible to distinguish between 'established parties' - save, perhaps, the 'communist successor' parties - and populist parties challenging them (e.g. Minkenberg 2013). Post-communist politics in many Central and Eastern European countries was characterised by a lack of continuity in party systems and party ideologies. Economic crises and corruption scandals furthermore provided an ostensibly favourable environment for populism. Public dissatisfaction was particularly high among the so-called 'transition losers' who did not reap the benefits from the free-market economy (Bustikova and Kitschelt 2009; March 2011: 139-41). Thus, according to Mudde (2007: 41), several parties in post-communist countries have gone through a populist radical right phase in their aim to tap into a general anti-political mood (see also Minkenberg 2002; Rupnik 2007; Pirro 2013). It has even been suggested that populism constituted a more general feature of post-communist politics, with populist rhetoric being voiced by radical and non-radical opposition parties alike (see Lang 2005; Učeň 2007).

This book nevertheless provides a study of populist parties across the whole of Europe, as excluding post-communist countries in comparative research becomes increasingly artificial. In the quarter of a century that passed after the fall of the Berlin Wall there have been substantial developments. Post-communist EU members, in particular, have been forced to abide by the economic as well as the political norms of Western European countries (Mudde 2002a: 229). At the same time, in view processes such as growing electoral volatility and partisan dealignment, Western European party systems have arguably began to resemble more closely the changeable systems in Central and Eastern Europe (see e.g. Dalton et al. 2000; Mair 2006; Van Biezen et al. 2011).

These arguments should not be pushed too far; particularly in the post-communist part of Europe many countries remain marked by widespread disenchantment with 
politics, unstructured party competition, and extremely weak ties between voters and parties (Rupnik 2007; Casal Bértoa 2013; Van Biezen and Wallace 2013). This may also affect the way in which populism manifest itself in this part of the continent, in the sense that populism might still be a more generic phenomenon in post-communist than in Western European politics.

In the next chapter, which identifies the populist parties across Europe, I discuss in more detail to what extent one can meaningfully use the concept of populism as a 'classifier' in both parts of Europe on the basis of the given definition. I will now first turn to the analytical framework related to the other core aim of this book: explaining the electoral performance of populist parties.

\section{[A] Explaining the electoral performance of populist parties}

For my analytical framework concerning populist party performance I seek inspiration from the wider literature on radical right, new or 'niche' parties. It can be expected that there is considerable overlap between the conditions determining the success or failure of populist parties and those related to the electoral performance of other non-mainstream parties. Below, I will nevertheless seek to clarify why several such conditions are expected to be relevant for the performance of populist parties in particular. For reasons of space, the review of findings from previous studies is concise, and I will refrain from going into depth with regard to these studies' methodological approaches and geographical scope. This is not to deny that these factors are important in accounting for the sometimes contradictory results in the literature.

Previous studies have regularly referred to broad societal developments as a cause of the breakthrough of new types of parties. Ronald Inglehart (e.g. 1977; 1997), for instance, described the growing salience of postmaterialist causes and the related rise of social liberal and green parties. Scholars such as Piero Ignazi (1992; see also 1996) and Hans-Georg Betz (1994), on the other hand, focused on the socio-economic and 
socio-cultural conditions favouring the rise of radical or extreme right parties (see also Taggart 1996; Swank and Betz 2003). It has been argued that processes such as the globalisation of markets, the decline of traditional (class) identities, and the related individualisation of society have generated cultural and economic anxieties among specific sections of the electorate, and fed into dissatisfaction with the established political systems. More recently, Kriesi et al. (2006; 2008) identified a new structural cleavage in Western European countries, pitting 'winners' and 'losers' of globalisation against each other.

The abovementioned studies have been valuable in clarifying the general breeding ground for parties outside the traditional mainstream - predominantly in Western Europe. Yet the identified trends do not explain cross-national differences in the success of populist parties, since they have affected countries in similar ways. It can thus be expected that populist parties have electoral potential across contemporary Europe, especially in view of the current 'availability' of voters. This relates to the previously mentioned process of partisan dealignment in Western Europe (see e.g. Dalton et al. 2000; Mair 2006; Krouwel 2012), and the fact that ties between voters and parties have remained weak across post-communist Europe (e.g. Rose 1995; Casal Bértoa 2013). To explain the varying electoral fortunes of populist parties between European countries, I therefore seek to select more country-specific explanatory conditions for my analytical framework.

One can, first of all, think of various institutional factors which have frequently been considered in past studies. Some of these have been discarded; Abedi (2004) and Carter (2005), for instance, found little evidence that requirements for ballot access, the availability of state subventions, or access to broadcast media had an impact on the vote for, respectively, anti-political establishment (APE) and extreme right parties (see also Harmel and Robertson 1985; Norris 2005; Bolin 2007). viii Several authors have also considered whether a federal state structure is conducive to new party success. A federal or decentralised structure may provide opportunities for new parties to enter legislatures at the sub-national level and to build regional strongholds. However, most studies found 
little evidence for an impact of federalism or territorial decentralisation on the success of new or extreme right parties (Harmel and Robertson 1985; Willey 1998; Arzheimer and Carter 2006; cf. Hakhverdian and Koop 2007).

The influence of another institutional variable, the electoral system, has also been considered frequently. The properties of an electoral system are relevant for new and small parties in particular, and populist parties often fall into these categories. A pure Proportional Representation (PR) system allows parties with a relatively small vote share to enter parliament, while other systems are designed to the advantage of larger parties. Specific features of electoral systems such as the district magnitude (the number of candidates to be elected per district) and the electoral threshold affect the proportionality of a system (see Carter 2005). A higher district magnitude normally leads to an allocation of seats which reflects more closely the distribution of votes, and benefits smaller parties (see Rae 1971).A higher electoral threshold, on the other hand, obstructs the entrance into parliament of parties with only a limited vote share. Besides the mechanical effects of electoral systems, also psychological effects are likely to be relevant (Duverger 1959). When the electoral system is disproportional, citizens may be reluctant to 'waste' their votes on parties that are perceived to stand relatively little chance to enter parliament. Electoral system characteristics, then, not only influence the allocation of seats after the election, but also the initial vote distribution. At the same time, political entrepreneurs may be less inclined to found a new party, if the hurdle posed by the electoral system is deemed too high.

Studies that considered the effect of the electoral system on the support for extreme right parties have yielded mixed results. Some scholars concluded that, under certain conditions, factors such as district magnitude and electoral thresholds matter for the performance of extreme right parties (Golder 2003; Jackman and Volpert 1996). Others found less or no evidence for the expectation that more proportional electoral systems are conducive to the extreme right vote (Norris 2005; Carter 2005; Van der Brug et al. 2005; Arzheimer and Carter 2006). This study, however, does not only consider populist parties of the radical right. The electoral system will be considered as 
an explanatory condition in this research, since several studies have shown that a more proportional electoral system favours the electoral performance, or the party system entrance, of new parties in general (Harmel and Robertson 1985; Willey 1998; Tavits 2006; Bolin 2007; cf. Abedi 2004). Although the electoral system alone is unlikely to determine the electoral performance of populist parties, there is sufficient reason to assume that it can be an important factor in combination with other explanatory conditions.

The electoral success or failure of populist parties cannot be understood without also considering the agency of political parties. Various scholars have assessed the ideological placement and tactics of mainstream parties in order to account for nonmainstream party performance. Studies have, for instance, found that convergence between mainstream parties, or the formation of a grand coalition, benefited (radical/extreme right) challenger parties (e.g. Kitschelt and McGann 1995; Abedi 2004; Carter 2005). Other scholars, however, did not find clear evidence for the ideological convergence thesis (Arzheimer and Carter 2006; Norris 2005; Veugelers and Magnan 2005).

It has been questioned, however, whether measuring party distances on a single left-right dimension is a valid way to study developments in party positions and strategies (Bornschier 2010: 6). Various different issue dimensions may be relevant in accounting for party competition dynamics (see Spies and Franzmann 2011). One way around this problem is to consider the policy dimension which is most relevant to the appeal of the parties under consideration (Meguid 2008: 49; Bornschier 2010). In view of the ideological diversity of populist parties across Europe, however, a general explanatory framework for their electoral performance needs to go beyond an assessment of the ideological space with regard to specific policy dimensions.

What is more, in addition to more substantive policy-related motivations, a vote for a populist party is assumed to be an expression of dissatisfaction with the political establishment (see Eatwell 2003; Bélanger and Aarts 2006; Oesch 2008; Schumacher and Rooduijn 2013). This dissatisfaction may not necessarily relate to party positions; it 
can also be the result of disappointment with established parties' accomplishments or neglect of specific issues (Rydgren 2005). I therefore expect that populist parties' electoral performance is above all related to the perceived responsiveness of established parties. It can be expected that populist parties thrive when established political parties are perceived to be unresponsive to the demands of 'the people'. This can relate to a notion that established parties fail to address certain salient issues or have become indistinct ideologically, but also to the more abstract perception that they have formed an impenetrable elitist cartel (see Katz and Mair 1995). If these views are sufficiently widespread, established parties are vulnerable to the rise of populist challengers (see also Hauss and Rayside 1978; Lucardie 2000; Hug 2001).

Established parties may, on the other hand, hamper the success of populist parties by successfully retaining or seizing the ownership of the issues central to the populist party's appeal (see Budge and Farlie 1983; Petrocik 1996). Tim Bale (2003), for instance, spoke of a 'black widow effect' when centre-right parties in office are able to capture the electoral support of their radical right junior coalition partner by copying its policies. Bonnie Meguid (2008) similarly argued that an 'accommodative' strategy of a mainstream party can reduce the electoral support for a niche party, but that the success of this strategy also depends on the strategies of the other mainstream parties (see also Bornschier 2010; 2012).

Notwithstanding the importance of the established parties' agency in explaining the performance of populist challengers, I suspect it is a mistake to treat the latter as mere 'by-products of competition between mainstream parties' (Meguid 2008: 22). In this study, therefore, an additional explanatory condition is the supply of credible populist parties. Even if the breeding ground for populism is fertile, populist electoral success would be lacking without the supply of a credible populist party. The importance of 'supply side' factors, such as party organisation and leadership, in explaining new, radical, or populist party performance has been acknowledged (e.g. Hauss and Rayside 1978; Betz 2002; Carter 2005; Rydgren 2005; Mudde 2007; Albertazzi and McDonnell 2008b; March 2011). In single case studies these factors are also regularly taken into 
consideration. Yet in comparative studies (of a quantitative nature) they have often been overlooked. This is hardly justifiable, following Cas Mudde's (2010) argument about populist radical right parties, since these parties' leadership, organisation, and campaigning are vital in explaining their success or failure to break through and survive.

The contribution of Elisabeth Carter (2005) is one of the few systematic comparative studies taking into consideration such supply-side factors. Carter found that party organisation and leadership are of key importance in explaining the varying levels of support for extreme right parties in Europe; strongly organised and well-led extreme right parties have been more successful (see also Lubbers et al. 2002; Givens 2005). Carter also found that the ideology of the extreme right relates to its electoral support; parties that are blatantly anti-democratic and adhere to classical racism are generally less successful (see also Schedler 1995; Rydgren 2005; Bos and Van der Brug 2010). There is no reason to assume that factors related to ideology, leadership and organisation are any less important for populist parties, and based on previous insights the credibility of populist parties will be assessed by taking into account two main indicators: electoral appeal and organisational cohesion.

For a populist party, electoral appeal is assumed to relate to the following factors in particular: its leadership's visibility and persuasiveness, and its ability to dissociate itself from both the political establishment as well as political extremism. In order to break through electorally, a populist party needs to be sufficiently visible and persuasive to seize the ownership of salient social issues. Potential voters must be convinced that the party is able to 'handle' the problems it identifies better than its opponents (Petrocik 1996). In relation to this, it is important that the populist party attracts sufficient media attention and that the party figurehead(s) make a strong impression during the election campaign (see Mazzoleni et al. 2003; Mazzoleni 2008). This is not to say that populist party voters are prone to simply vote for the most 'attractive' leader (see Bellucci et al. 2013), but skilled leadership is required to raise attention to, and support for, the party's substantive arguments. 
At the same time, a populist party's electoral attractiveness is likely to remain limited when its policy positions are overly militant, or when the party is associated with political extremism (Rydgren 2005). Important to note is that it partly depends on the political context and the dominant political attitudes whether a party is considered too extreme or not (Mudde 2007: 259; Eatwell 2003). ${ }^{\text {ix }}$ Particularly after their breakthrough, the appeal of populist parties is likely to wane if they fail to stick convincingly to their anti-establishment discourse. This is a challenge especially for those populist parties that enter government, as they become part of the governing elite they used to oppose (Taggart 2000; Mény and Surel 2002). Once populist parties take part in office they are not necessarily doomed electorally (see Albertazzi and McDonnell 2005; 2010; Zaslove 2012; Akkerman and de Lange 2012), but it becomes at least more of a challenge for them to still present themselves as 'outsiders' in a convincing way. Government participation, in other words, can be seen as the 'ultimate test' for populist parties (Betz 2002; Heinisch 2003).

The second main indicator of credibility, organisational cohesion, is also vital to the electoral persistence of populist parties (Mudde 2007). After their breakthrough, populist parties are likely to lose their credibility as competent political actors if they fail to preserve internal discipline and cohesion. Since populist parties are often leadercentred organisations in practice, they are especially likely to fall apart when the leader departs or loses grip over the party (Betz 2002; Heinisch 2003). Other organisational factors, such as the degree of internal democracy or effective internal leadership (see Mudde 2007; De Lange and Art 2011), are not considered in this study as long as they remain purely internal affairs. Intra-party procedures are not normally visible to the electorate at large and are, therefore, unlikely to affect the party's image to the outside world. This is not to deny that these factors may have an indirect effect on the credibility of populist parties; sound internal leadership can, for instance, improve organisational cohesion and prevent publicly visible rows and defections.

By considering the credibility of populist parties as one of the key causal conditions, my study departs from the notion that that such parties only rely on 
uninformed protest votes. Even if populist parties thrive on resentment and disenchantment, there is more to their electoral performance than the presence of antiestablishment sentiments alone. Studies have, in fact, indicated that ideological convictions and policy preferences play a crucial role with regard to the right-wing populist vote (e.g. Van der Brug et al. 2000; 2005; Ivarsflaten 2008; Arzheimer 2009). This is expected to be no different for populist parties in general. These parties need to convince voters that they can handle salient issues in a better way than the established parties, and that they are therefore a credible alternative to the traditional political elites.

In addition to the three more fundamental conditions identified (the electoral system; the responsiveness of established parties; and the supply of credible populist parties), I expect that populist parties stand a better chance if certain issues are electorally salient. As discussed, populist parties may adopt various ideological colours, depending on the social and political context they operate in. That does not mean, however, that the populist thin ideology is entirely unrelated to the policies they focus on and positions they take. For instance, the fact that populist parties envision the the people' as a homogeneous entity, and define themselves against the establishment, has consequences for their substantive policy platform. As I will discuss below, populist parties in Europe are likely to focus on the following issues or themes in particular: 1) culture and ethnicity; 2) economic hardship; 3) European integration; and 4) corruption. It is important to note that these four themes are not relevant to (the performance of) all populist parties. I nevertheless expect that the breeding ground for populist parties is especially fertile where related issues are salient and where established parties are considered unresponsive or incapable to deal with them.

The first theme of culture and ethnicity is relevant for many populist parties, since populism's anti-pluralist character and homogeneous portrayal of 'the people' is very compatible with a culturally exclusivist vision of society. Indeed, it is this vision that characterises the many populist parties in Europe that can be placed in the populist radical right (PRR) category (Mudde 2007). Following Mudde (2007: 22), the key ideological feature of these parties is 'nativism', meaning: 'an ideology, which holds that 
states should be inhabited exclusively by members of the native group ("the nation") and that non-native elements (persons and ideas) are fundamentally threatening to the homogeneous nation-state'. The PRR's nativism is related to different themes across Europe. Whereas in Western European countries nativism is primarily expressed by an anti-immigration attitude - and, more recently, hostility towards I slam - immigration has hardly played a role in the political debates of post-communist countries. Here, the PRR tends to target ethnic minority groups, and in some countries the Roma population in particular (e.g. Mudde 2005; Bustikova and Kitschelt 2009; Pirro 2013; Minkenberg 2002; 2013).

As far as the electoral performance of radical right parties is concerned, many scholars have considered the volume of immigration or the presence of ethnic minorities as independent variables. Studies have yielded mixed results; some scholars found that higher levels of immigration, or a large number of foreign citizens, stimulated support for the radical or extreme right (Knigge 1998; Lubbers et al. 2002; Golder 2003; Swank and Betz 2003; Arzheimer 2009; Smith 2010). Others found no (significant) correlation (Kitschelt and McGann 1995; Van der Brug et al. 2005; Norris 2005; Arzheimer and Carter 2006; Messina 2007). Rather than considering objective numbers of immigrants and minorities in trying to explain PRR performance, in any case, it might make more sense to focus on subjective indicators: the prevalence of nativist attitudes within a given electorate, and the ability of populist parties to mobilise related grievances (see Van der Brug et al. 2005; Lubbers et al. 2002; Ivarsflaten 2008; Oesch 2008). Populist parties with a nativist ideology are likely to perform better if a large number of voters actually care about issues related to immigration and minorities, and subscribe to cultural protectionist ideas.

Not all populist parties, however, have a nativist character. Radical left-wing populist parties are defined primarily by their socio-economic economic policies and their aim to promote the rights of the underprivileged (March and Mudde 2005; March 2011). For these parties, economic hardship, the second theme identified here, is likely to be more relevant to their electoral performance. Particularly in periods of mass 
unemployment left-wing populists can make the case that the political establishment is more concerned with the interests of the capitalist elite than those of the ordinary worker. Yet economic hardship can be expected to benefit populist parties without a leftwing ideology as well, if the economic situation instigates a more general mood of dissatisfaction with the political establishment.

Economic variables, such as unemployment and inflation, have actually often been included in studies on the performance of the radical right. Again, results have been mixed; some scholars found that high levels of unemployment (under certain conditions) facilitated the vote for extreme right parties (Jackman and Volpert 1996; Golder 2003; Arzheimer 2009), whereas others found a negative relationship between levels of unemployment and extreme right support (Knigge 1998; Lubbers et al. 2002; Arzheimer and Carter 2006). Arzheimer and Carter (2006: 434) speculated that 'people may turn (back) to the more established and experienced mainstream parties in times of economic uncertainty rather than to the parties of the extreme right that lack such experience'. Others have argued that the state of the economy is unlikely to be a key driver behind electoral success of populist radical right parties, because these parties tend to concentrate more on cultural, rather than economic, issues (Mudde 2007; Bornschier 2010). Several studies indeed indicated that radical right parties have mobilised primarily on the basis of cultural grievances (e.g. Oesch 2008; Ivarsflaten 2008; Spies 2013). A study on the broader category of anti-political establishment parties also found little evidence that levels of unemployment are related to APE party performance (Abedi 2004).

In my study economic hardship is nevertheless considered to serve as a potential catalyst for populist party success for two reasons. First, the economic situation may not be relevant for the performance of all populist parties, but it may be for some. March and Rommerskirchen (2012), for instance, found that radical left parties performed better in times of high unemployment. For those populist parties that juxtapose the people (the 'plebs') against economic elites and their political allies, economic malaise may well provide a favourable opportunity structure. Especially in post-communist countries, 
demand for populist parties may have grown after the dismantling of communist welfare states and the subsequent growth of economic inequality (Bustikova and Kitschelt 2009).

Secondly, the financial and economic crisis that broke out in 2008 is likely to have increased the salience of issues such as unemployment and welfare state reforms across the whole of Europe. This may not only have benefited left-wing populist parties, but also have encouraged populist radical right parties to revise and prioritise their economic policies, in an attempt to appeal to the 'losers of globalisation' who oppose immigration, and also feel challenged economically (see Kriesi et al. 2006; 2008). Indeed, Van der Brug and Van Spanje (2009) showed that there is a substantial number of people in Western Europe who are left-leaning on socio-economic matters and right-leaning on immigration. In times of crisis, economic protectionism and 'welfare chauvinism' - the idea that welfare entitlements should be reserved for the native population - may have become more central and electorally rewarding for populist radical right parties than before.

Related to the economic crisis in Europe is the third theme of European integration. The EU's complex and opaque institutional set-up is something which populist parties are prone to oppose (Taggart 2004). In view of the populist love for transparency and hate for backroom deals, shady compromises, and complicated technicalities, Canovan (1999: 6) argued that European Union politics resembles a 'sitting duck' for populist attacks. Indeed, European integration is a process which is opposed by populist parties across the board. Populist radical right parties tend to see the European Union as a 'foreign' threat to the sovereignty of their nation, while left-wing populists often portray the EU as a neo-liberal project that encourages a 'race to the bottom' in terms of welfare entitlements and working conditions (see Hooghe et al. 2002; De Vries and Edwards 2009). The bailouts for financially troubled countries and proposals to pool more sovereignty to the European level in response to the Eurocrisis can be expected to have fuelled Eurosceptic sentiments, and possibly also the electoral salience of European integration (see Werts et al. 2012; March and Rommerskirchen 2012). 
Populist parties thus had an incentive to emphasise their opposition to Europe even more than before the crisis (Albertazzi and Mueller 2013: 365; Pirro and Van Kessel 2013).

The fourth theme that is likely to feature in the anti-establishment rhetoric of populist parties is corruption. This issue relates to the populist ideology very closely, since it links in directly with the normative distinction between the 'pure' people and the mendacious elites. Populist parties can be expected to perform well if there is a perception that the political establishment is corrupt, or characterised by patronage and cronyism (see Kitschelt and McGann 1995). As discussed, these themes have been particularly salient in the post-communist context; in many Central and Eastern European countries corruption has been considered an endemic problem (Mudde 2002a; Rupnik 2007; Pirro 2013). Here, populist party performance may not only be related to voters' judgments about the established parties' policy record, but also to perceptions about the more fundamental trustworthiness of the political elite.

It is worth mentioning that the four selected themes may overlap to a certain extent in the discourse of populist parties. For example, the theme of European integration may be related to economic as well as cultural grievances, and gravy trainriding 'Eurocrats' are also regularly accused of being corrupt. The interrelatedness of the themes is not necessarily a problem for the analysis, however, as it is assumed that the electoral fortune of populist parties depends on a combination of explanatory conditions. This will be further discussed in the final section of this chapter.

To summarise, in this study I consider three fundamental conditions in the aim to explain the electoral performance of populist parties: the electoral system; the responsiveness of the established parties; and the supply of credible populist parties (see Figure 1.1). Populist parties are expected to be more successful in an environment characterised by a proportional electoral system, a perception that established political parties are unresponsive, and a presence of credible populist challengers. I expect the absence of these conditions to be conducive to the failure of populist parties. In addition, I identified four themes that typically feature in the discourse of populist parties, and that may therefore also be relevant to their electoral performance: culture and ethnicity; 
economic hardship; European integration; and corruption. If these themes are salient, populist parties can be expected to perform better at the polls, particularly when established parties are perceived to be unresponsive with regard to these themes. This is not to argue that all four themes are relevant for all populist parties. The relevance of the themes is largely dependent on the political context and the ideological features of a given populist party.

\section{*** FIGURE 1.1 ABOUT HERE ***}

One final point to raise about this explanatory model is that similar variables can arguably be identified to study the electoral performance of new 'challenger' parties in general. Other non-populist parties that are critical of the establishment are equally likely to thrive when there is widespread dissatisfaction with mainstream parties (see, for instance, Kitschelt (1988) and Müller-Rommel (1998) on left-libertarian parties and green parties, respectively). All parties, moreover, are likely to fail if they do not present themselves as credible actors. For populist parties, however, the perceived failure of the established parties is of particular importance, as they are defined by their antiestablishment appeal and their supposed aim to make politics responsive to the ideas and interests of the ordinary people. For this research, in addition, the concept of 'credibility' is operationalised so that it applies to populist parties in particular. These parties are credible insofar as they manage to voice a convincing, yet not overly extremist, anti-establishment rhetoric. Organisational cohesion, furthermore, is especially relevant for populist parties, as they are often weakly institutionalised and therefore more vulnerable if internal conflicts occur. Finally, as explained, the four selected themes relate to issues which are typically central to the appeals of populist parties.

Whether the electoral performance of populist parties truly relies on a different logic compared with the performance of other parties, however, has to become clear from the analyses in this study. The final section of this chapter outlines in more detail how the study is designed. 


\section{[A] Research design, methodology and plan of the book}

Two aims are central in this book: to identify populist political parties in contemporary Europe (between 2000 and 2013) and to explain their electoral performance. In order to fulfil the first aim, I studied relevant literature on specific countries and parties. Not for all 31 countries under consideration there was an abundance of secondary literature to rely on. Where required and possible, therefore, primary party literature was also examined. In addition, I consulted country experts in order to validate the selection and description of cases, and to fill in missing pieces of information. The list of country experts consulted is provided in Appendix A, and Appendix B includes a template of the questionnaire that was sent to them. ${ }^{x}$ Election results were mainly derived from the website Parties and Elections in Europe (Nordsieck 2013).

In order to explain the identified populist parties' performance in national elections, the study triangulates a broad analysis of 31 countries with three in-depth case studies. Both parts of the analysis take the explanatory framework outlined in Figure 1.1 as a starting point, although they have a different focus. The first part, in which Qualitative Comparative Analysis (QCA) techniques are applied, focuses mainly on the breeding ground for populist parties across a wide range of European countries. The three case studies that follow are primarily meant to unravel the causal mechanisms underneath populist party performance, and focus more specifically on the party competition between populist and established parties. This mixed-methods approach is also taken in order to increase the validity of the study's findings. The two parts are complementary, as the QCA analysis is aimed at identifying broad causal patterns, whereas the case studies assess the plausibility of these patterns by considering particular cases in detail (Lieberman 2005).

Instead of using conventional statistical approaches, such as regression analysis, this study turns to QCA techniques for the first part of the analysis (see e.g. Ragin 1987; 2000; 2008; Rihoux and Ragin 2009; Schneider and Wagemann 2012). QCA is a comparative approach, geared to demonstrate causal complexity and 'multiple 
conjunctural causation'. This means, firstly, that the QCA approach assumes that it is often a combination of causal conditions that leads to a certain outcome. Consequently, in QCA terminology the term 'causal condition' is used instead of 'independent variable', as QCA steps away from the 'additivity' assumption that single variables have their own independent impact on the outcome. QCA, in addition, departs from the 'uniformity of causal effects' notion that a single causal condition has the same effect across contexts. The effect of one single condition may instead vary across cases, depending on the presence or absence of other causal conditions.

Relatedly, QCA is based on the assumption that different combinations of causal conditions may relate to the same outcome. This notion of 'equifinality' is of particular importance in my study, since different contextual factors and political issues are likely to be relevant for the wide variety of populist parties across Europe. The proportionality of an electoral system, for example, may be of greater importance to new and small populist parties than to older and sizeable populist parties, such as the Austrian Freedom Party and the Swiss People's Party. As discussed, corruption and economic hardship may play a larger role for populist parties in post-communist countries than they do for their counterparts in some longer-established democracies in Western Europe. It may thus be possible to discern different 'paths' to populist success - and failure for that matter depending on the relevance of certain conditions and issues in a given country. QCA is the appropriate method to identify those paths.

Several more specific features and potential drawbacks of QCA will be discussed in Chapter 3, which presents the fuzzy set QCA analysis (or put simply: 'the fsQCA'). One issue important to mention here is that countries are taken as the unit of analysis in the QCA, since in this part of the study I am interested in the breeding ground for populist parties across European countries. The analysis is therefore primarily based on countrylevel data. The four identified themes play a central role in the aim to assess whether there are various paths leading to populist success or failure. Can we, for instance, observe a better performance of populist parties where people hold nativist and Eurosceptic views, where the economy is in a bad shape, and where there are high 
perceived levels of corruption? And do we observe different outcomes in countries where one or more of these conditions are absent?

The QCA will thus focus specifically on the socio-cultural, socio-economic and socio-political conditions related to the four selected themes, but also provides an analysis including the three more general explanatory factors: the electoral system; the responsiveness of established parties; and the supply of credible populist parties. In this medium $\mathrm{N}$-research design it is unfortunately difficult to assess precisely whether established parties have been responsive to voters with regard to specific issues. As a proxy for the established parties' responsiveness in a given country, citizens' more general perceptions of the quality of democracy and political institutions will be used (see Chapter 3). The credibility of populist parties is similarly difficult to operationalise quantitatively. In view of the assumed importance of this causal condition, however, a rudimentary assessment of the credibility of populist parties in all 31 countries is made in Chapter 2. The outcomes of this assessment will be used in the QCA in the subsequent chapter.

A final note concerning the time-span of the analysis is that the period of study ranges between 2000 and 2013. Since party systems in many post-communist countries were still in flux in the years after the transition to democracy, analysing elections since the turn of the $21^{\text {st }}$ century is assumed to lead to a more meaningful pan-European comparison. As the QCA is aimed at assessing cross-national, and not cross-temporal variation, the average percentage of the vote for populist parties in each country across this period is taken as a measurement for the outcome variable. Similarly, average figures are used for the measurement of the causal conditions, most of which are expected to have remained rather stable during the period of study (see Chapter 3 for more details). Yet since the financial and economic crisis at the end of the 2000s may have influenced the conditions and the performance of populist parties, a separate analysis is performed using data from more recent years only. This additional analysis also serves to assess the robustness of the findings from the first analysis. 
After the QCA, the book will continue with the three in-depth case studies. In this part of the study, particular emphasis will be placed on the responsiveness of established parties concerning the issues central to the appeal of the populist challengers, as well as the credibility of populist parties themselves. The three chapters will also seek to explain cross-temporal variation in the electoral performance of individual populist parties. The selected cases are the Netherlands, Poland and the United Kingdom. The case selection is, first of all, based on the need to include cases from both Western- and postcommunist Europe. In this way, the performance of populist parties can be compared across countries with a fundamentally different political background, in which different issues are likely to rank high on the political agenda.

The Netherlands and Poland are selected, because both countries provide an ideal 'laboratory’ environment for learning about the electoral performance of populist parties. Both countries have witnessed the rise and fall of populist parties since the start of the century, and in both countries populist parties have entered government. The Netherlands and Poland are thus countries in which successful and unsuccessful manifestations of populism can be compared, which makes the two cases especially suitable in order to gain understanding of the electoral performance of populist parties in general. The United Kingdom is selected as a third, 'negative', case. The UK is one of the countries in Europe where populist parties have thus far been unsuccessful in national elections. The British case, in addition, is characterised by the Single Member Plurality electoral system that is applied in general elections. The UK thus lends itself particularly well to study the effect of a disproportional electoral system on the fortunes of populist parties.

The case studies rely on a variety of methods and data sources. In order to identify the populist parties in the three countries and to learn about their ideological characteristics, qualitative content analyses of party manifestos and other party documents have been performed. In addition, several semi-structured interviews with country experts and politicians were carried out (see Appendix D for the list of interviewees). Besides providing information about the characteristics of the various 
populist parties, these interviews also shed light on the factors relevant to their electoral performance. In addition, expert surveys were composed and sent out to country experts in the three selected countries (see Appendix E for an example of the survey). Findings from these surveys substantiated the identification of populist parties and were also used to validate the analysis of the populist parties' electoral performance. I finally made use of existing opinion poll and election study data, as well as insights from the secondary literature.

Having outlined the conceptual, theoretical and methodological starting points of the study, the next chapter of this book proceeds with identifying the populist parties in the 31 countries under consideration. It will become clear that this is not a straightforward exercise, for instance because populism is not always a lasting attribute of political parties, and sometimes only expressed to a certain degree. Many borderline cases can be found in post-communist countries in particular. After having selected the 'full' cases of populism, Chapter 3 presents the design and results of the QCA. The outcomes indicate that the credibility of populist parties is of vital importance to their electoral performance, while contextual conditions and dominant public attitudes alone cannot account for populist success or failure. The three case studies are presented in Chapters 4, 5 and 6 . They confirm the importance of the credibility condition; established parties may create a favourable opportunity structure when they neglect certain salient social issues or ruin their own reputation as trustworthy representatives of the people, but populist parties are to a large extent responsible for their own success or failure. This also applies to populist parties competing under unfavourable electoral rules, as the analysis of the British case suggests. Chapter 7, finally, revisits and reflects on the findings of the study, and touches on their implications and avenues for further research. 


\section{Notes}

\section{I ntroduction: Studying Populism in European Party Systems}

'European Commission President Barroso spoke these words at the annual Brussels Think Tank Forum on 22 April 2013 (European Commission 2013a).

ii See e.g. Van Spanje (2011), Mudde (2007), and Carter (2005) for a discussion about the terminology used to describe such parties; various adjectives such as 'radical right', 'extreme right', 'far right', and 'anti-immigrant' are used rather inconsistently by different authors. I choose to stick to 'radical right' in this book.

iii See also the record of the conference that yielded this volume in Government and Opposition (Berlin et al. 1968).

iv Since populists may be inclined to criticise certain specific 'elite actors' in practice, I am hesitant to argue that populism treats the 'elite' category as a homogeneous unit.

$\checkmark$ The definition deviates somewhat from the one in previous publications that stemmed from this research project (Van Kessel 2011; 2013). This more recent definition captures the essence of populist parties more precisely.

vi Collier and Mahon (1993: 849) use the example 'mother'; even if a woman is not the genetic mother of a child, and hence does not belong to the central subcategory, she might still be categorised as a 'nurturing mother' or a 'stepmother'.

vii In an interview with the author Dutch politician Rita Verdonk, for instance, saw the term 'populist' as an honorary adjective: 'Populi means the people, and I am there for the people. And there's nothing wrong with that' (The Hague, 18 December 2008).

viii Abedi's definition of anti-political establishment parties, a concept coined by Andreas Schedler (1996), overlaps considerably with well-known definitions of populism. It is questionable, however, whether all the parties identified by Abedi as APE parties (including Green Parties and Orthodox Christian Parties) truly fit the definition.

ix Radical anti-immigration parties in Germany, for instance, are especially prone to stigmatisation due to the legacy of the Second World War (e.g. Decker 2008). In some Central and Eastern European countries where xenophobic sentiments are widespread, on the other hand, political 
mainstream parties are found that voice extremist rhetoric (targeting for instance Jewish people and Roma) (see Mudde 2005).

${ }^{x}$ For some cases the list of questions was more tailored, if the aim was to collect specific information about populist parties in a particular country. 